\title{
EKSPLORASI VEGETASI MANGROVE DI PESISIR LHOK BUBON ACEH BARAT
}

\section{THE EXPLORATION OF MANGROVE VEGETATION AT THE COAST OF LHOK BUBON WEST ACEH}

\author{
${ }^{1}$ Mohamad Gazali \\ ${ }^{1}$ Prodi Ilmu Kelautan, Fakultas Perikanan dan Ilmu Kelautan, Universitas Teuku Umar \\ Jalan Alue Peunyareng, Meulaboh, Aceh Barat 23615, Aceh ,Telepon (0655) 7003087
}

Korespondensi: mohamadgazali@utu.ac.id

\begin{abstract}
ABSTRAK
Salah satu komponen ekosistem pesisir dan laut adalah hutan mangrove. Hutan mangrove mempunyai fungsi ekologi yang penting, seperti peredam gelombang dan angin, pelindung pantai dari abrasi, penahan lumpur dan penangkap sedimen yang diangkut oleh aliran air, sebagai daerah asuhan dan tempat mencari makan serta merupakan tempat pemijahan. Tujuan penelitian ini adalah untuk mengeksplorasi vegetasi mangrove yang ada di Pesisir Lhok Bubon Aceh Barat. Metode kegiatan eksplorasi dilakukan dengan mengkoleksi semua tumbuhan yang sedang untuk dijadikan spesimen herbarium. Tumbuhan yang telah diketahui nama marga dan jenisnya dicatat guna melengkapi data kekayaan jenis yang ada. Berdasarkan hasil penelitian menunjukkan bahwa terdapat 8 spesies mangrove yang tersebar di 3 stasiun pengamatan di pesisir Lhok Bubon. Keanekaragaman spesies mangrove masih rendah dibandingkan dengan daerah lainnya. Kondisi spesies mangrove sudah diekploitasi untuk memenuhi kebutuhan hidup atau aktivitas wisata pantai yang meliputi sampah plastik dan bahan pencemar lainnya yang mengganggu ekosistem mangrove.
\end{abstract}

Kata kunci : Eksplorasi, vegetasi mangrove, Lhok Bubon

\section{ABSTRACT}

One of the marine and coastal ecosystem components were mangrove forest. Mangrove forest had impontantly ecological fucntion such as the reducing of wave and wind, the protection of the beach from abrassion, to retain muddy and trapping of sediment from water flow, nursery ground, feeding ground, and spawning ground. The aims of this research is to explore the mangrove vegetation at the coast of Lhok Bubon West Aceh. The exploration method with collecting all plants to become herbarium specimens. The plants that knows their name of marga and species were noted for completing the data of species richness. According to the result showed there are 8 mangrove species that distributed in 3 stations of observation in the coast of Lhok Bubon. Species biodiversity of mangrove were still low compared with other area. The mangrove species circumstances are already exploited for requiring the livelihood or beach tourisms including plastic waste and other pollution that disturbed mangrove ecosystem.

Keywords : exploration, mangrove vegetation, Lhok Bubon

\section{PENDAHULUAN}

Indonesia merupakan negara kepulauan yang memiliki 17.508 pulau dengan luas laut sekitar 5,8 juta $\mathrm{km}^{2}$ dan bentangan garis pantai sepanjang $81.000 \mathrm{~km}$ (Dahuri et al., 1996). Sepanjang garis pantai terdapat berbagai macam tumbuhan bakau (mangrove) yang merupakan salah satu dari sumber yang mendapatkan perhatian di wilayah pesisir. Fungsi hutan mangrove sebagai spawning ground, feeding ground, dan nursery ground. Selain itu, hutan mangrove sebagai tempat penampung sedimen sehingga hutan mangrove merupakan ekosistem dengan tingkat produktivitas yang tinggi dengan berbagai macam fungsi ekonomi, sosial dan lingkungan yang penting. 
JURNAT \A (O)TI ILMU KELAUTAN

Volume I, Nomor 1, 2019

Menurut Undang-Undang No. 41 Tahun 1999 tentang kehutanan, hutan adalah suatu kesatuan ekosistem berupa hamparan lahan berisi sumberdaya alam hayati yang didominasi pepohonan dalam persekutuan alam lingkungannya, yang satu dengan lainnya tidak dapat dipisahkan sedangkan arti kata mangrove adalah vegetasi hutan yang tumbuh diantara garis pasang surut, tetapi juga tumbuh pada pantai karang, pada dataran koral mati diatas ditimbuni selapis tipis pasir atau ditimbuni lumpur atau pantai berlumpur (Saparinto, 2007).

Salah satu komponen ekosistem pesisir dan laut adalah hutan mangrove. Hutan mangrove mempunyai fungsi ekologi yang penting, seperti peredam gelombang dan angin, pelindung pantai dari abrasi, penahan lumpur dan penangkap sedimen yang diangkut oleh aliran air, sebagai daerah asuhan dan tempat mencari makan serta merupakan tempat pemijahan bermacammacam biota perairan, sebagai penyubur perairan karena menghasilkan detritus dari seresah daun yang diuraikan oleh bakteri menjadi zat hara (Bengen 2001a). Selain itu produk dari mangrove dapat dihasilkan baik secara langsung ataupun tidak langsung sebagai kayu bakar, bahan bangunan, keperluan rumah tangga/perkakas, bahan kertas,bahan tekstil, alat perikanan, pupuk pertanian dan obat-obatan (Noor, Khazali dan Suryadiputra 1999). Irawan (2005) melaporkan bahwa keberadaan hutan mangrove dapat memperkecil resiko akibat dampak tsunami di Propinsi Aceh. Daerahdaerah yang memiliki front zonasi mangrove kerusakannya tidak terlalu parah jika dibandingkan dengan daerah yang tidak memiliki front hutan mangrove.
Available online at:

http://utu.ac.id/index.php/jurnal.html

Adanya perubahan lingkungan ekosistem wilayah pesisir laut secara tidak langsung akan mempengaruhi sistem komunitas yang berada di dalamnya (Irawan 2003), termasuk terhadap keanekaragaman jenis dan struktur komunitas yang berada dalam ekosistem tersebut.

Vegetasi mangrove Lhok Bubon memperoleh tekanan lingkungan dari kegiatan antropogenik yang bersumber dari kegiatan wisata pantai. Kegiatan tersebut dapat menghasilkan sampah yang akan yang dibuang disekitar vegetasi mangrove. Selain itu, kegiatan konversi hutan mangrove untuk tambak dan tempat wisata pantai juga memberikan dampak menurunnya populasi hutan mangrove. Oleh karena itu pada penelitian ini ingin diketahui mengenai kondisi vegetasi mangrove di Pesisir Lhok Bubon Aceh Barat.

Rumusan masalah yang dapat diajukan dalam penelitian ini adalah untuk mengetahui kondisi vegetasi mangrove berdasarkan jenis-jenis mangrove penyusun komunitas, keanekaragaman jenis mangrove, serta status kondisi komunita mangrove. Hasil penelitian ini diharapkan dapat dijadikan sebagai salah satu alat pelengkap yang menjadi bahan kajian dalam upaya pengelolaan oleh para pengambil kebijakan serta sebagai informasi ilmiah yang berguna bagi masyarakat dan berbagai pihak dalam upaya pelestarian dan perlindungan di kawasan pesisir Lhok Bubon Aceh Barat Propinsi Aceh.

\section{METODE PENELITIAN Waktu dan Tempat}

Penelitian ini dilakukan di Pesisir Lhok Bubon Kabupaten Aceh Barat Propinsi Aceh. Pengambilan data di lapangan dilakukan di sekitar pesisir pantai, serta pengolahan data 


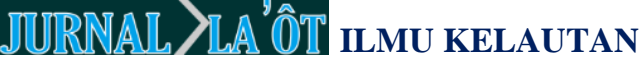

Volume I, Nomor 1, 2019

dilakukan di Laboratorium MIPA Terpadu Universitas Teuku Umar. Penelitian ini dilakukan pada bulan Januari 2019. Titik koordinat pengambilan sampel terdiri dari 3 stasiun meliputi stasiun $1 \quad\left(4^{0} 11^{\prime} 43.5^{\prime} \times \mathrm{N}\right.$, $\left.96^{0} 01^{\prime} 30.8^{\prime \prime} \mathrm{E}\right), \quad$ stasiun $2 \quad\left(4^{0} 11^{\prime} 44.0^{\prime} \mathrm{N}\right.$, $\left.96^{0} 01^{\prime} 27.6^{\prime \prime} \mathrm{E}\right)$ dan stasiun $3\left(4^{0} 11^{\prime} 52.4^{\prime} \mathrm{N}\right.$, 9601'38.3’'E).
Available online at:

http://utu.ac.id/index.php/jurnal.html

\section{Alat dan bahan penelitian}

Peralatan yang dibutuhkan dalam pengambilan data adalah : Global Positioning System (GPS), kompas, kamera digital, rol meter, calipers, hagameter, pita transek atau tali rafia, lux meter, sling, kertas $\mathrm{pH}$, hand refracto salinometer dan tabel data. Bahan penelitian meliputi komunitas mangrove yang dijumpai di lokasi penelitian.

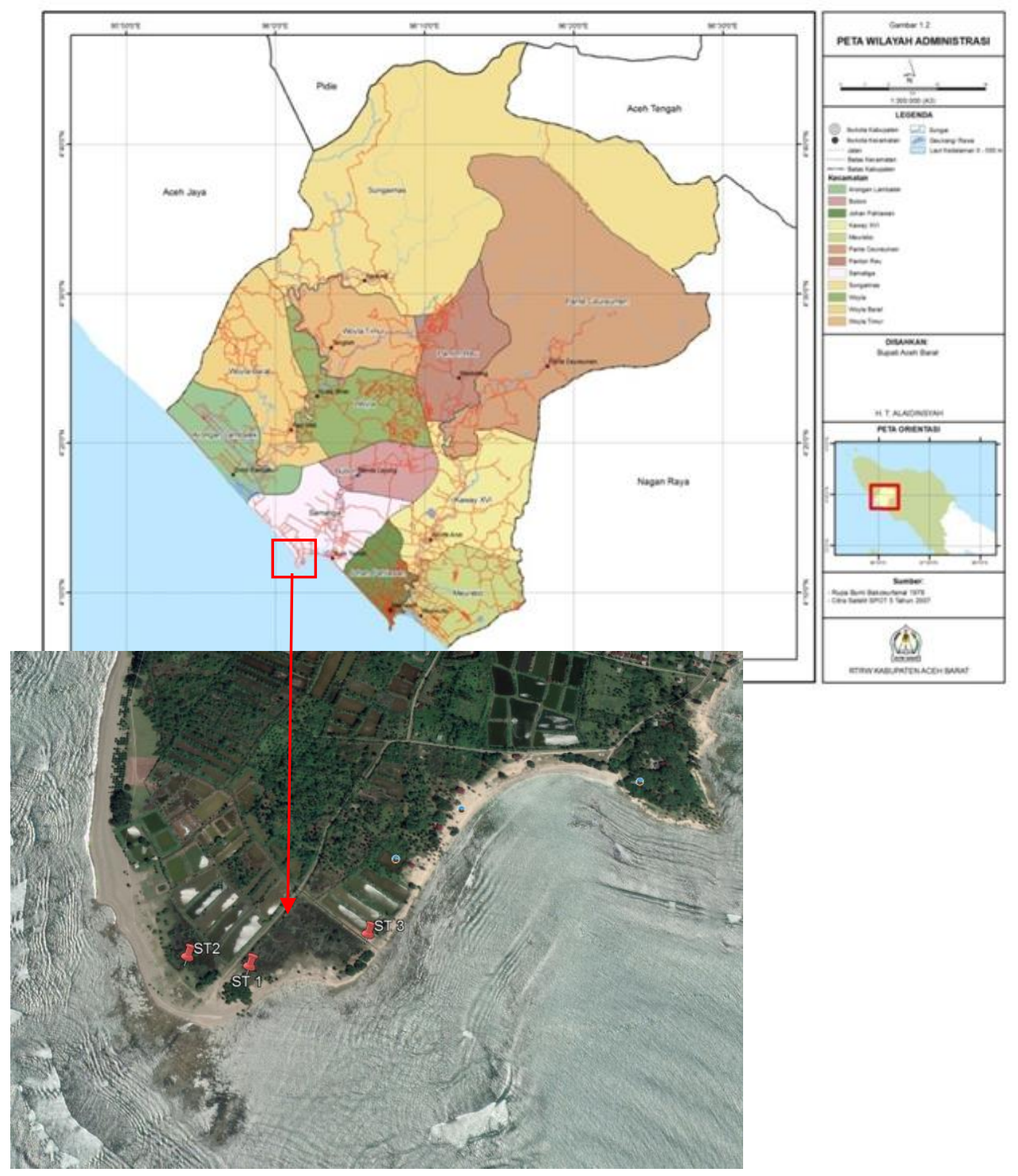

Gambar 1. Lokasi Penelitian 


\section{JURNAT \A (O)TI ILMU KELAUTAN}

Volume I, Nomor 1, 2019

\section{Koleksi Tumbuhan}

Koleksi tumbuhan dilakukan dengan mengumpulkan sampel tumbuhan yang diawetkan untuk pembuatan specimen herbarium kering. Sampel tumbuhan yang akan diambil diusahakan memiliki organ tumbuhan yang lengkap. Setiap sampel tumbuhan yang dikoleksi diberi nama dan nomer kolektor serta tanggal dan lokasi pengoleksian dengan menggunakan label gantung.

Setiap sampel disimpan ke dalam lipatan kertas koran, kemudian dimasukkan ke dalam kantung plastik koleksi dan disiram spirtus atau alkohol secukupnya. Pengerjaan pressing dan mounting dilakukan di Laboratorium MIPA Terpadu Universitas Teuku Umar. Data-data tumbuhan yang dikumpulkan digunakan untuk menyusun checklist keanekaragaman tumbuhan mangrove.
Available online at:

http://utu.ac.id/index.php/jurnal.html

\section{Metode Penelitian}

Metode Kegiatan eksplorasi dilakukan dengan mengkoleksi semua tumbuhan yang sedang berbunga atau berbuah untuk dijadikan spesimen herbarium. Tumbuhan yang tidak sedang berbunga/berbuah terutama yang ada potensinya, maupun yang sering kali dijumpai diambil sebagai spesimen bukti (voucher), tumbuhan yang telah diketahui nama marga maupun jenisnya dicatat guna melengkapi data kekayaan jenis yang ada.

\section{HASIL DAN PEMBAHASAN}

\section{Keadaan umum hutan mangrove}

Desa Lhok Bubon merupakan daerah pesisir pantai yang memiliki aktivitas antropogenik yang cukup tinggi meliputi pencemaran sampah plastik yang dibuang sembarangan di sekitar vegetasi mangrove (Gambar 2).

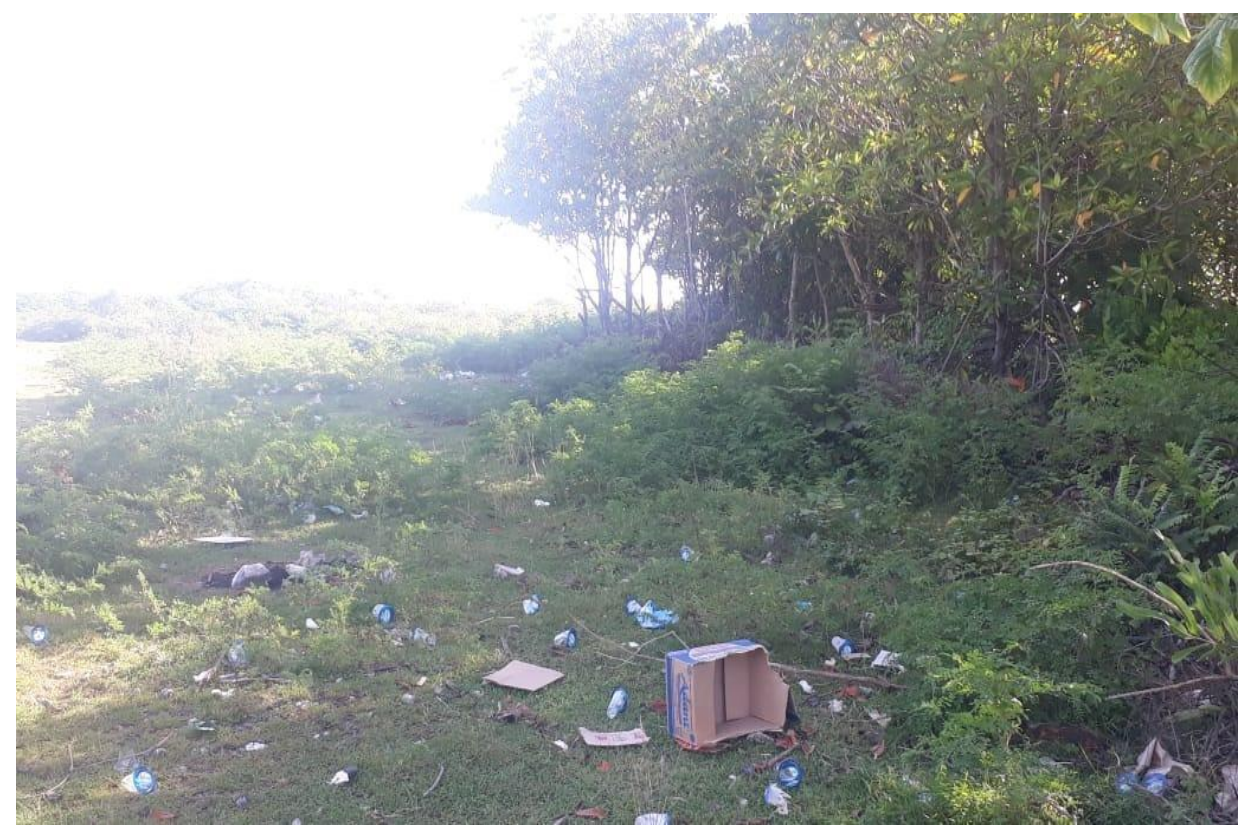

Gambar 2. Vegetasi Mangrove yang tercemar sampah plastik 


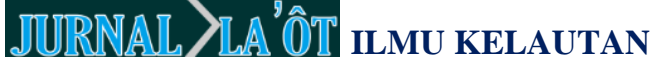

Volume I, Nomor 1, 2019
Available online at:

http://utu.ac.id/index.php/jurnal.html

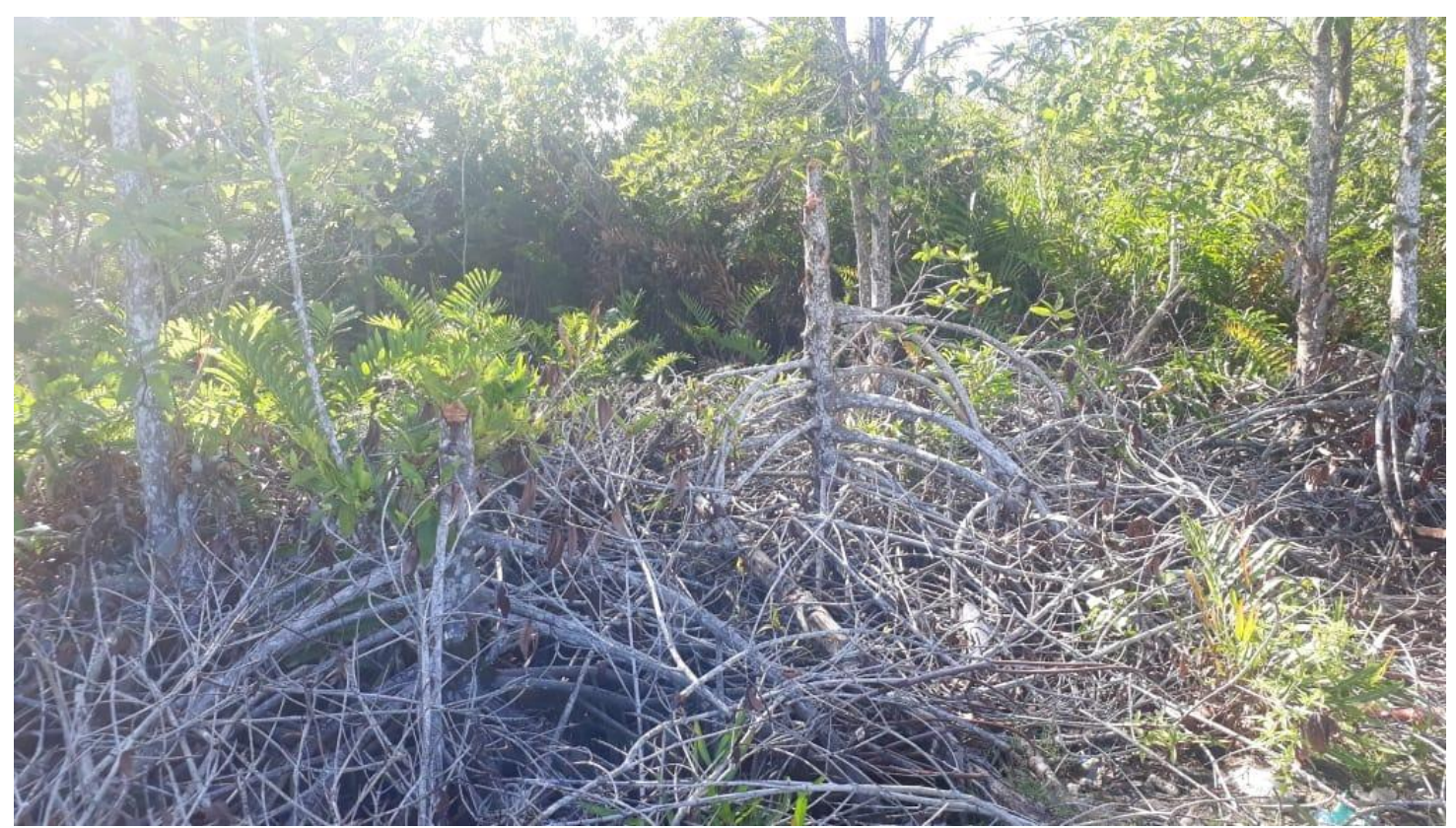

Selain itu, adanya aktivitas pariwisata ekosistem mangrove mengalami kepunahan

yang berada di sekitar vegetasi mangrove akibat dari deforestasi hutan mangrove. menyebabkan masyarakat lokal menebang vegetasi mangrove untuk keperluan hidup mereka (Gambar 3).

Daftar Spesies Mangrove di Pesisir Lhok Bubon Aceh Barat

\begin{tabular}{llccc} 
Suku & Spesies & Stasiun I & Stasiun 2 & Stasiun 3 \\
\hline Rhizophoraceae & Bruguiera gymnorrhiza & - & - & + \\
Rhizophoraceae & Rhizophora apiculata & + & + & + \\
Sonneratiaceae & Sonneratia alba & + & + & + \\
Arecaceae & Nypa fruticans & + & + & - \\
Pteridaceae & Acrostichum speciosum & + & + & + \\
Malvaceae & Hibiscus tiliaceus & - & + & + \\
& & - & & + \\
Combretaceae & Terminalia catappa & & - & + \\
Convolvulaceae & Ipoema pes caprae & - & + & + \\
\hline
\end{tabular}

Ket : + = ditemukan ; - = Tidak ditemukan

Penebangan pohon mangrove di sekitar Hasil Eksplorasi Vegetasi Mangrove tempat pariwisata menyebabkan menurunnya populasi mangrove. Banyak biota-biota mangrove yang sangat bergantung pada

Berdasarkan hasil eksplorasi pada stasiun 1 terdiri dari spesies Rhizophora apiculata, Sonneratia alba, Nypa fruticans dan Acrostichum aureum. Diantara spesies mangrove tersebut yang mendominasi adalah 


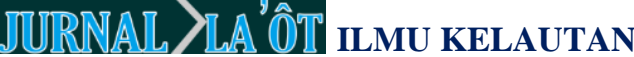

Volume I, Nomor 1, 2019

spesies Sonneratia alba. Pada stasiun 1 memiliki subsrat berlumpur dimana banyak tersebar makrozoobentos pada stasiun tersebut. Pada stasiun 1 tidak terlalu jauh dari

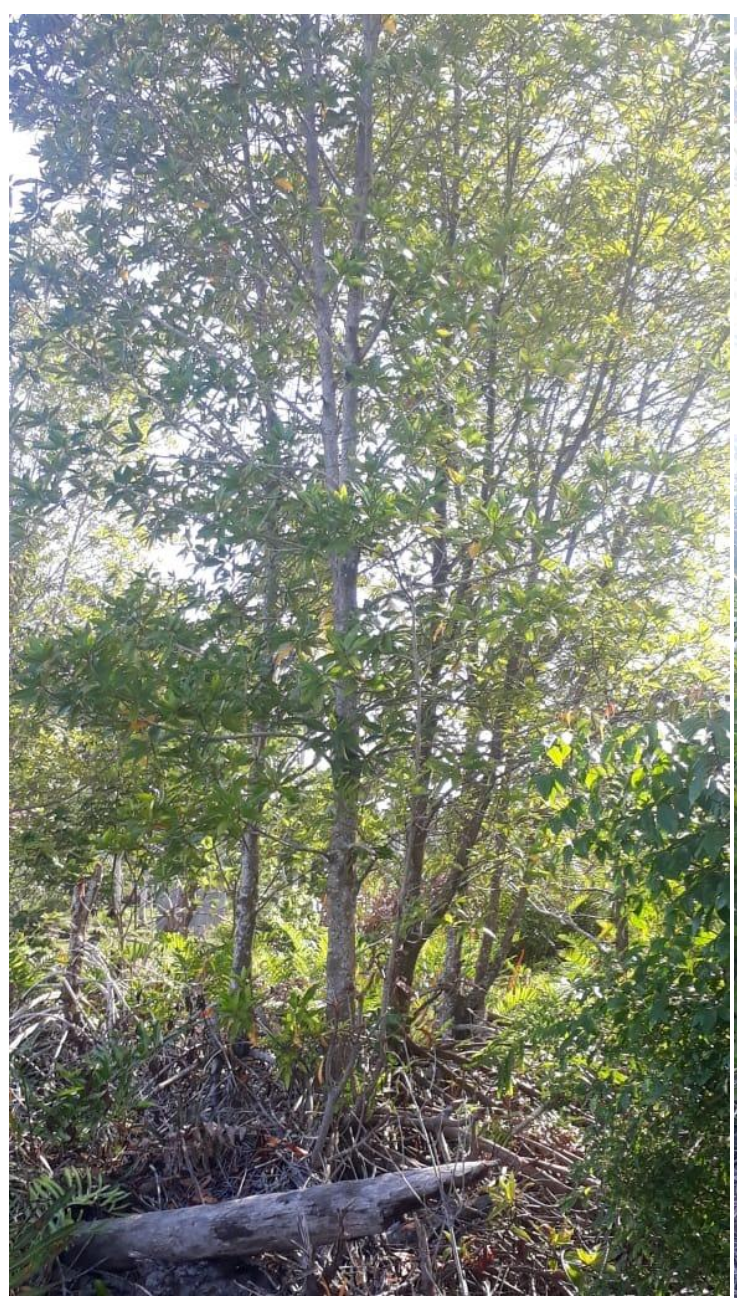

Gambar 4. Spesies R. apiculata

pesisir pantai Lhok Bubon diperkirakan sekitar \pm 550 meter dari daratan (Tabel 1).

Spesies B. gymnorrhiza hanya terdapat pada stasiun 3 yang berdekatan dengan lokasi wisata pantai dimana tingkat eksploitasi vegetasi mangrovenya cukup tinggi. Sementara spesies $R$. apiculata terdapat pada ketiga stasiun. Spesies ini
Available online at:

http://utu.ac.id/index.php/jurnal.html

sering dimanfaatkan oleh masyarakat lokal sehingga kadangkala ditebang (Gambar 4).

Spesies Sonneratia alba merupakan spesies mangrove yang mendominasi pada

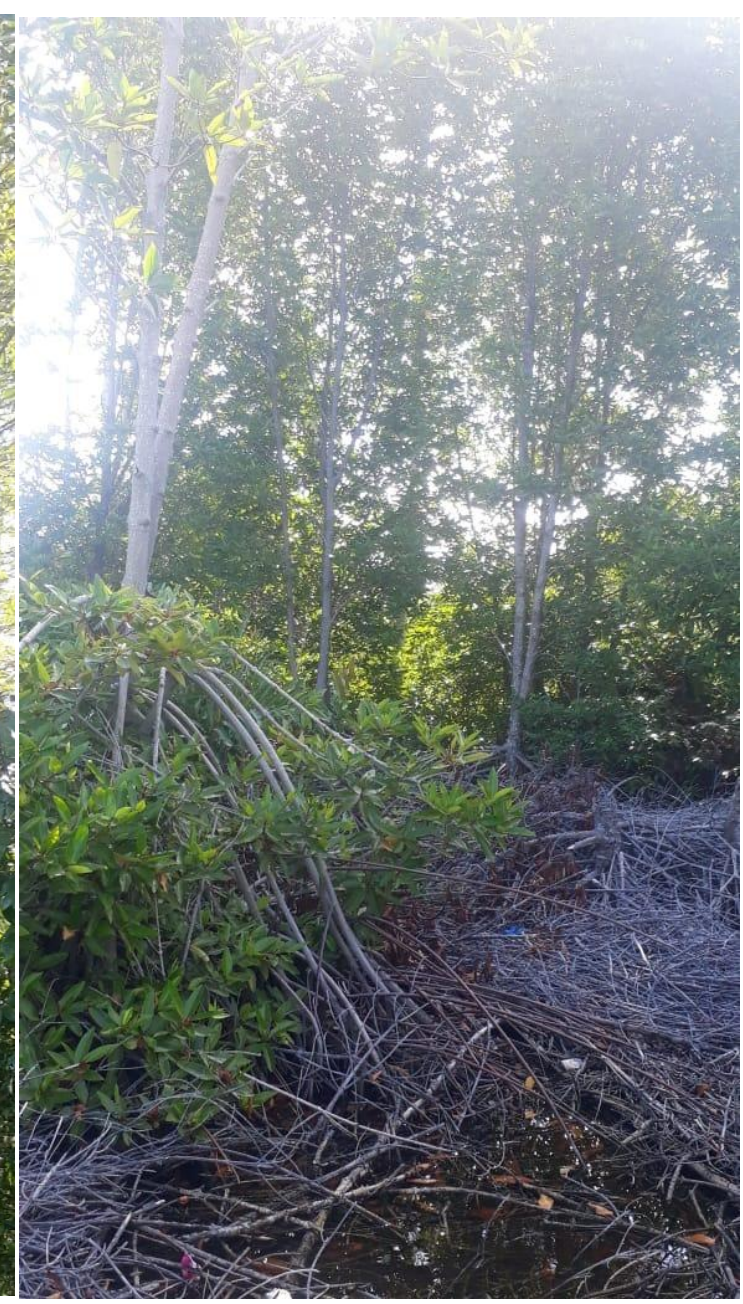

setiap stasiun pengamatan. Tipe akar pada spesies $S$. alba berupa akar nafas vertikal yang muncul pada permukaan substrat berlumpur (Gambar 5). Distribusi spesies $S$. alba pada substrat yang berlumpur. Di pesisir Lhok Bubon terdapat bekas-bekas karang mati yang cocok bagi substrat spesies $S$. alba. Spesies ini tersebar secara terpencar-pencar dan berasosiasi dengan spesies $R$. apiculata 
IIURNAL > ILA' ÔTI ILMU KELAUTAN

Volume I, Nomor 1, 2019
Available online at:

http://utu.ac.id/index.php/jurnal.html

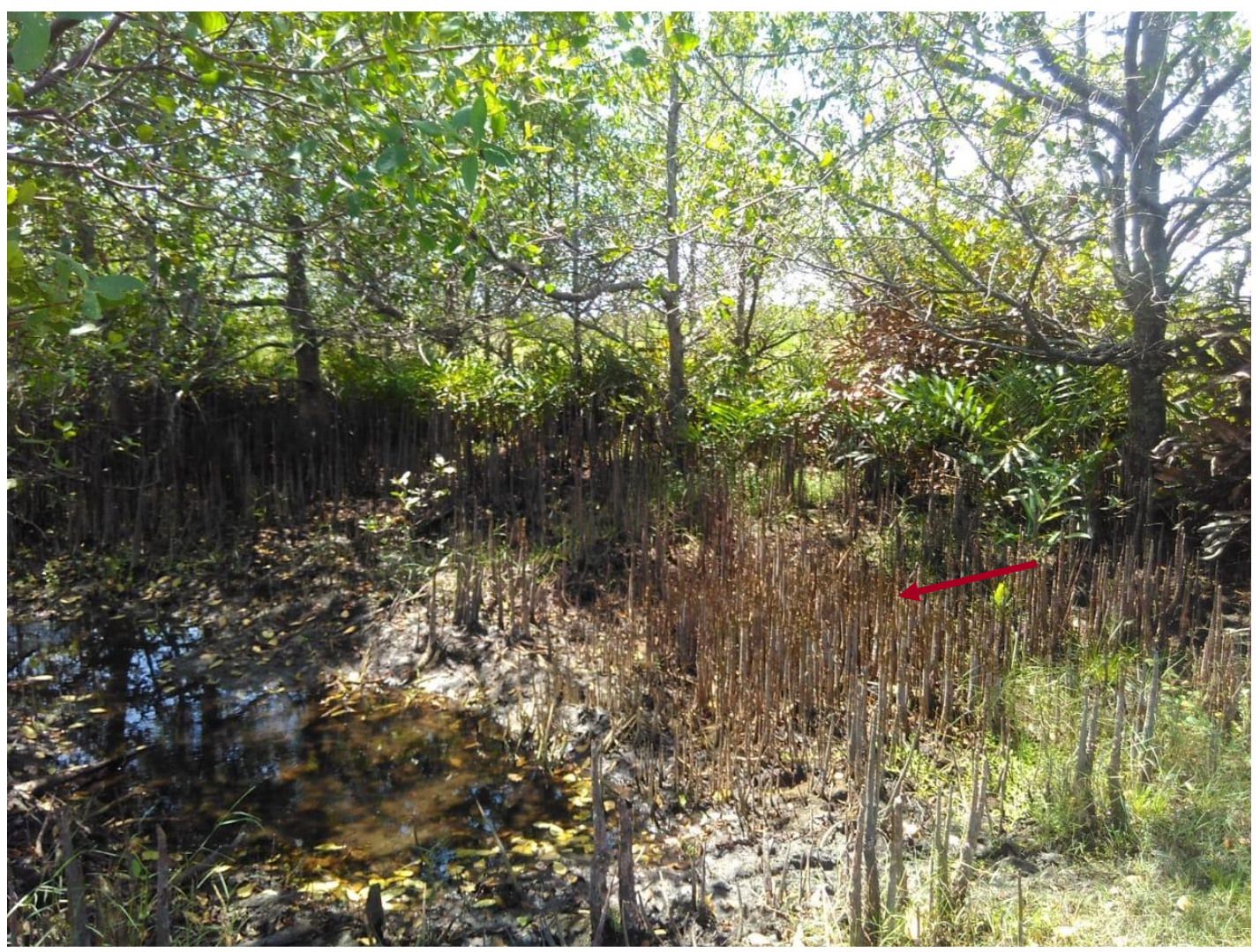

Gambar 5. Akar napas vertikal spesies $S$. alba

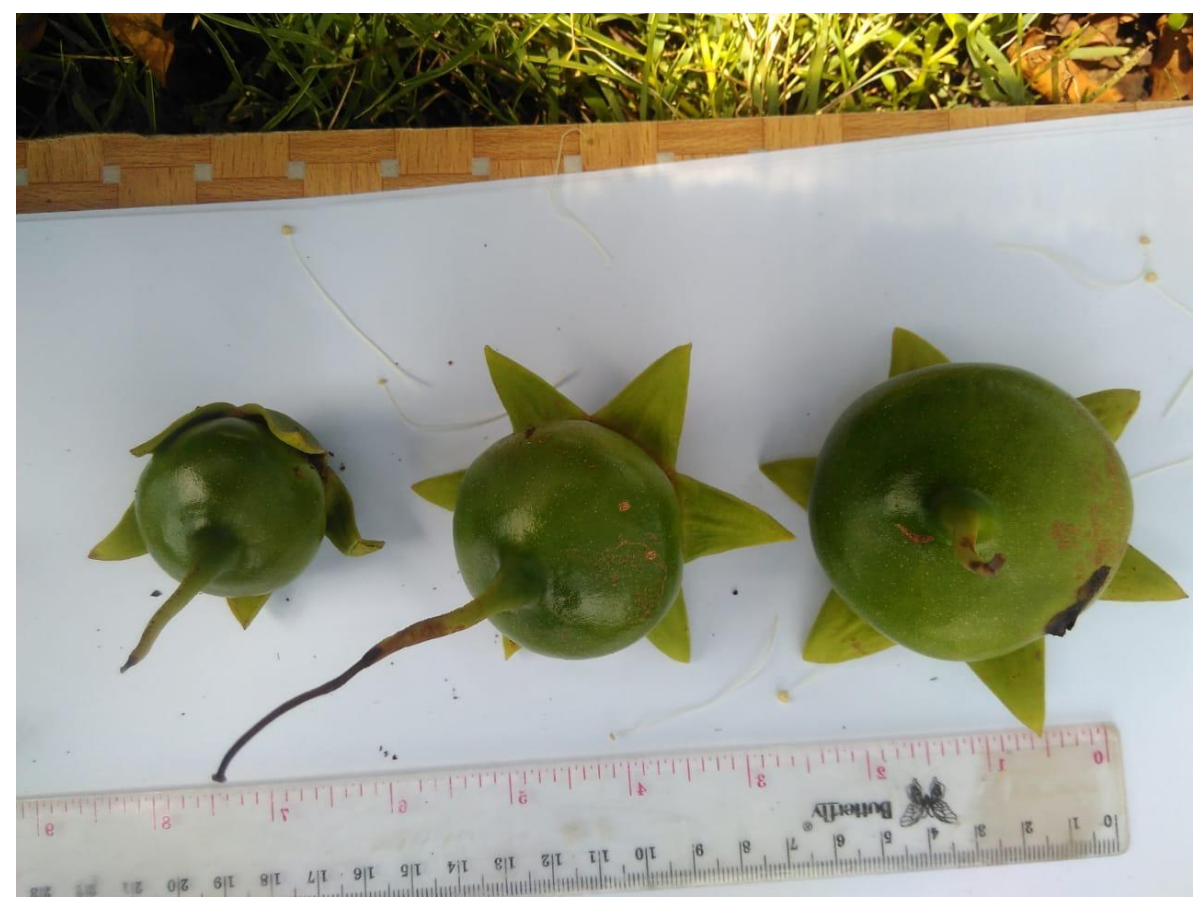

Gambar 6. Bentuk buah spesies S. alba 


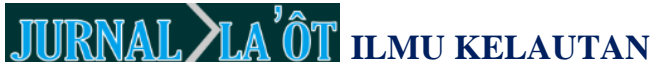

Volume I, Nomor 1, 2019
Available online at:

http://utu.ac.id/index.php/jurnal.html

Buahnya berbentuk seperti bola yang pada bagian ujungnya bertangkai dan pada bagian

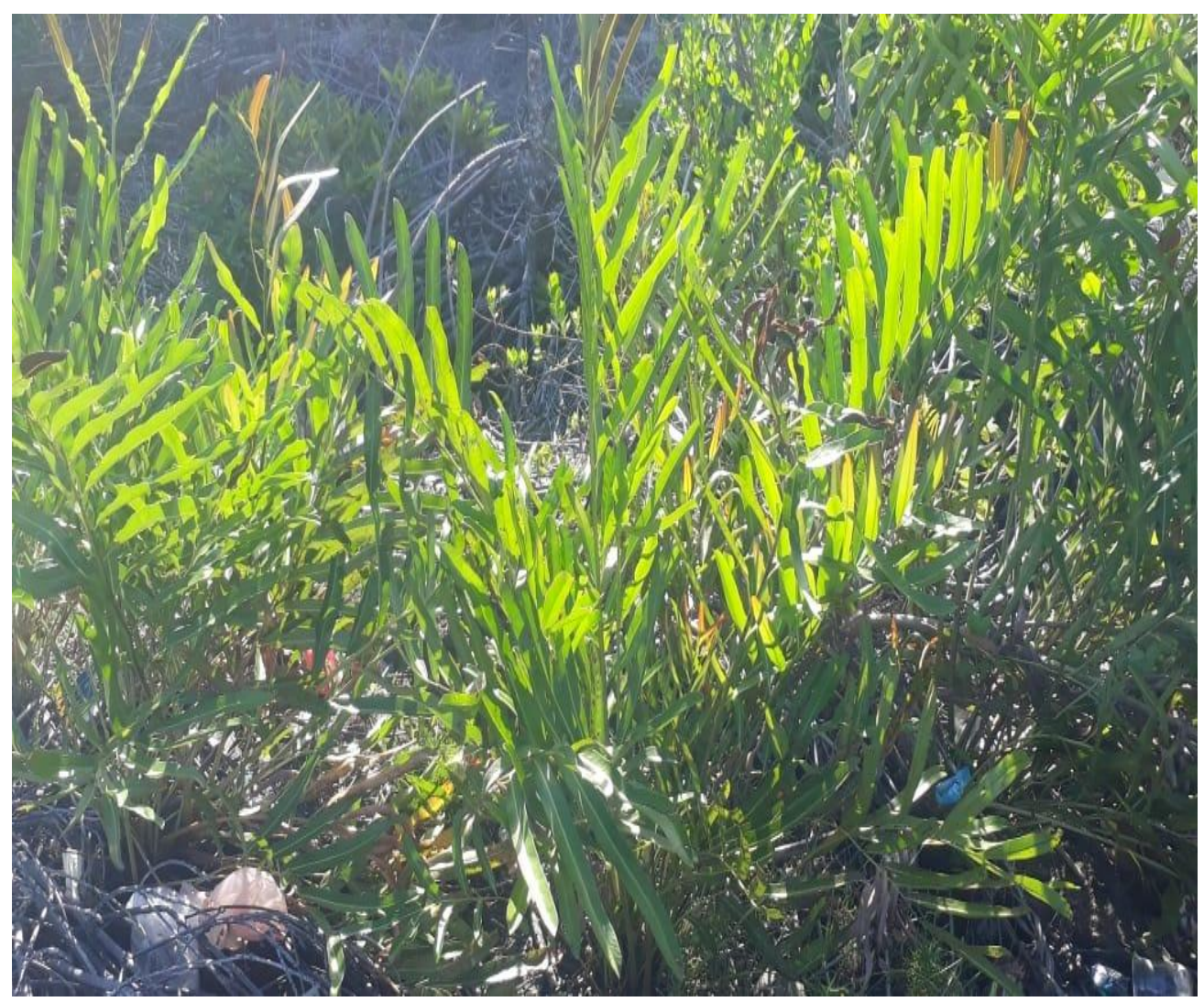

Gambar 7. Distribusi spesies A. speciosum

dasar terbungkus kelopak bunga. Buah nya sangat harum menyerupai buah apel. Oleh karena itu, spesies $S$. alba dijuluki sebagai apple mangrove (Gambar 6). Daunnya berbentuk telur terbalik pada bagian ujungnya membundar. Daunnya berwarna hijau muda sampai hijau tua.

Pada spesies A. speciosum merupakan spesies mangrove yang tersebar dimanamana. Spesies ini biasanya tumbuh berdekatan dengan vegetasi mangrove lainnya atau di pematang tambak. Ferna tanah membentuk tandan yang kasar dengan ketinggian hingga 1,5 m. Sisik pada akar rimpang. Daunnya sangat mencolok pada umumnya panjangnya kurang dari $1 \mathrm{~m}$ dan memiliki pinal daun fertil berwarna karat pada bagian ujung daunnya runcing dan memanjang (Gambar 7).

Spesies $N$. fruticans merupakan mangrove sejati yang tersebar luas pada stasiun 1 dan stasiun 2 yang mengarah ke daratan. Spesies N. fruticans berasosiasi dengan vegetasi mangrove spesies $R$. apiculata dan S. alba. Spesies $N$. fruticans tumbuh didekat daratan atau estuaria yang masih dipengaruhi oleh pasang surut air laut. Spesies $N$. fruticans memiliki buah berbentuk bulat seperti buah pandan dengan panjang bonggol hingga mencapai $45 \mathrm{~cm}$. Spesies $N$. fruticans dimanfaatkan oleh masyarakat lokal sebagai sumber pangan dan obat-obatan. 


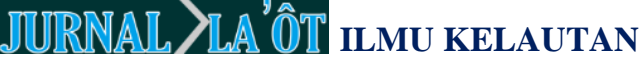

Volume I, Nomor 1, 2019

Gazali (2019) melaporkan bahwa daun tumbuhan $N$. fruticans memiliki aktivitas antioksidan yang kuat sehingga dapat dijadikan sebagai sumber pangan dan non pangan. Tumbuhan nipah ( $N$. fruticans)
Available online at:

http://utu.ac.id/index.php/jurnal.html

Mangrove ikutan adalah kelompok tumbuhan yang berasosiasi dengan mangrove sejati dan tidak memiliki adaptasi khusus seperti halnya tumbuhan mangrove sejati. Namun tumbuhan mangrove ikutan tersebut memiliki toleransi

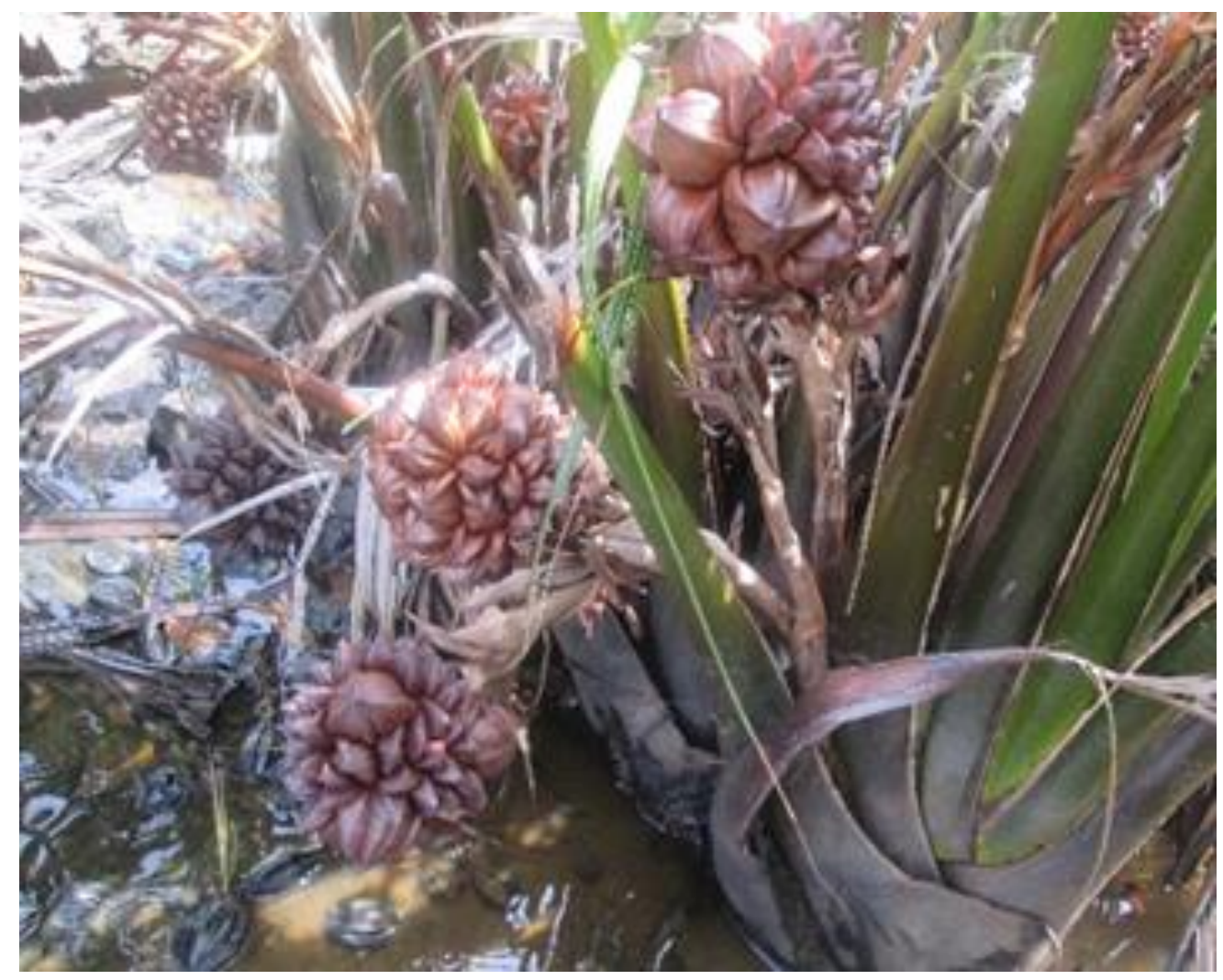

Gambar 8. Spesies N. fruticans

berkhasiat sebagai obat sinusitis (Bayu, 2009). (Gambar 8). Sahoo et al (2012) juga mengungkapkan bahwa nipah ( $N$. fruticans) mengandung polifenol, tannin dan alkaloid.

Vegetasi mangrove $N$. fruticans ini dimanfaatkan oleh masyarakat lokal mulai dari daun muda sebagai pembungkus rokok tradisional. Buah $N$. fruticans dapat dijadikan sebagai jus minuman segar.

Selain itu, Pesisir Lhok Bubon tersebar mangrove ikutan meliputi Hibiscus tiliaceus, Terminalia catappa dan Ipoema pes caprae. yang tinggi dalam lingkungan yang ekstrim.

Pada stasiun 2 dan stasiun 3 terdapat vegetasi mangrove ikutan $H$. tiliaceus. Masyarakat lokal menyebut spesies $H$. tiliaceus sebagai waru laut. Spesies tersebut banyak tersebar di formasi dekat pantai Lhok Bubon. Spesies H. tiliaceus dijadikan tempat teduh bagi wisatawan lokal yang berkunjung ke wisata pantai Lhok Bubon (Gambar 9). 


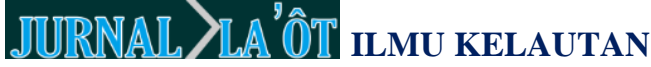

Volume I, Nomor 1, 2019
Available online at:

http://utu.ac.id/index.php/jurnal.html

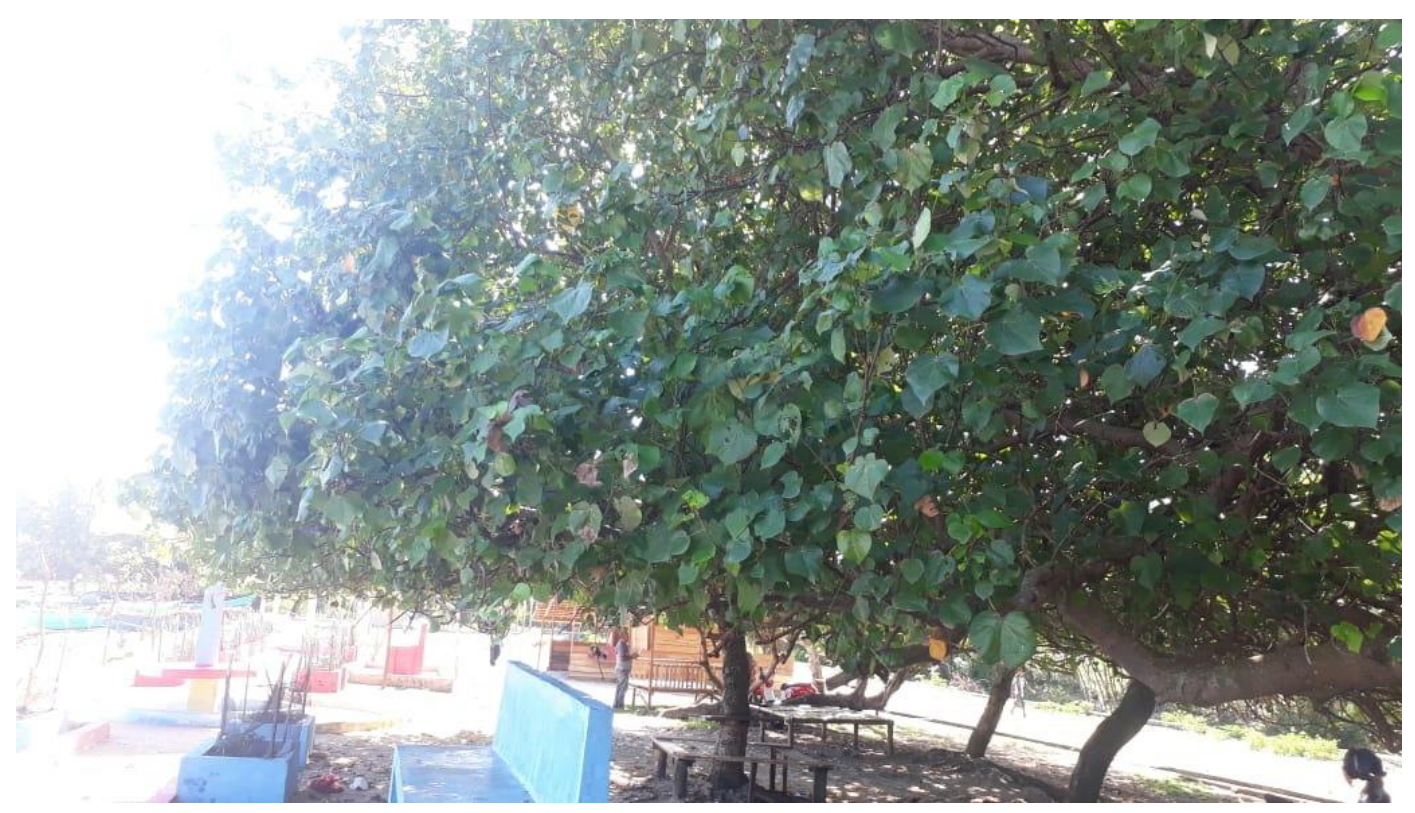

Gambar 9. Mangrove ikutan H. tiliaceus

Spesies T. catappa terdapat pada stasiun 3 yang berdekatan dengan aktivitas manusia yaitu melakukan kegiatan wisata

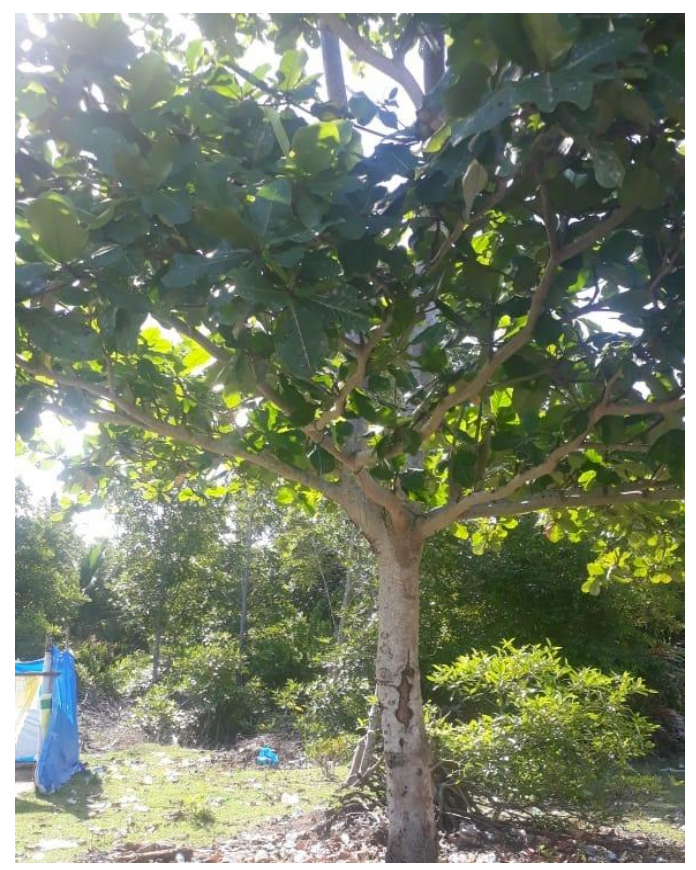

Gambar 10. Habitat spesies T. catappa pantai. Spesies T. catappa merupakan pohon yang berada di tepi pantai yang biasanya digunakan sebagai tempat teduh. T. catappa memiliki buah yang berbentuk bulat telur gepeng bersegi (Gambar 10).

Spesies Ipomea pes caprae adalah mangrove ikutan yang tumbuh berkembang di daerah pesisir pantai Lhok Bubon. Spesies Ipomea pes caprae lebih dikenal dengan tumbuhan tapal kuda. Tumbuhan ini kebanyakan menjalar pada substrat pasir.

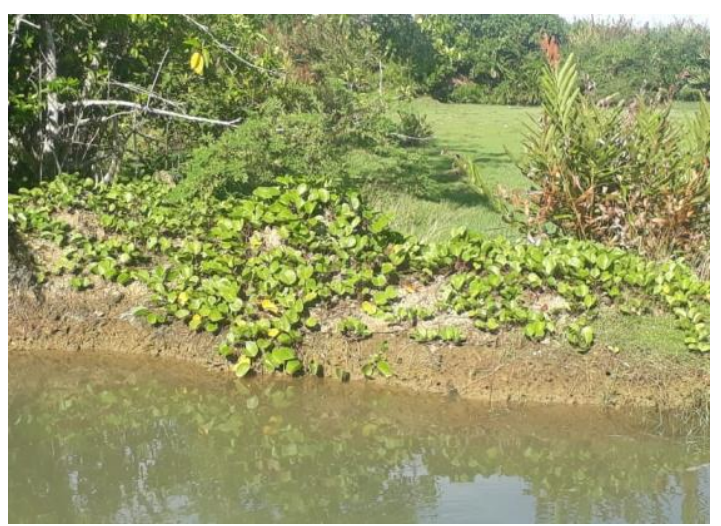

Gambar 11. Habitat spesies Ipomea pes caprae 
JURNAT \A (O)TI ILMU KELAUTAN

Volume I, Nomor 1, 2019

Akan tetapi, spesies Ipomea pes caprae di pesisir Lhok Bubon terdapat di daerah agak jauh dari pantai dan berdekatan dengan daerah estuaria. Ramanathan et al (2012) melaporkan bahwa daun katang-katang di pesisir India berpotensi sebagai antioksidan dan penangkap radikal bebas. (Gambar 11).

Biodiversitas spesies mangrove di kawasan pesisir Lhok Bubon masih rendah jika dibandingkan dengan biodiversitas spesies mangrove yang ada di kawasan hutan mangrove di Pulau Gosong Aceh Singkil, tercatat 27 jenis (Suhardjono, 2001), di Pulau Unggas, Air Bangis, Pasaman tercatat 18 jenis (Hermalena et al., 1999), di Teluk Mandar, Polewali, Propinsi Sulawesi Selatan tercatat 28 jenis (Pramudji, 2003), Di Pesisir Teluk Kayeli, Pulau Buru, Maluku tercatat 25 jenis (Parmudji dan Sediadi, 1999), di Muara sungai Siganoi, Sorong Selatan, Papua tercatat 12 jenis (Rahawarin, 2005) dan di Teluk Kertasari. Namun Kawasan Pesisir Lhok Bubon memiliki biodiversitas lebih tinggi daripada yang ada di Sumbawa Barat tercatat hanya 7 jenis (Jupri, 2006).

\section{KESIMPULAN DAN SARAN Kesimpulan}

Berdasarkan hasil penelitian bahwa terdapat 8 spesies mangrove baik mangrove sejati maupun mangrove ikutan yang ada di kawasan pesisir Lhok Bubon Aceh Barat. Berdasarkan hasil observasi secara bahwa dari ke delapan spesies mangrove yang paling mendominasi dalam setiap stasiun adalah spesies $S$. alba.

\section{Saran}

Untuk memperoleh data yang akurat terkait keanekaragaman vegetasi mangrove diperlukan kajian kuantitatif hutan mangrove terkait dengan kerapatan per spesies.
Available online at:

http://utu.ac.id/index.php/jurnal.html

\section{UCAPAN TERIMA KASIH}

Peneliti mengucapkan terima kasih kepada Muhammad Nurdin yang membantu dalam melakukan observasi lapangan terkait penelitian ekologi mangrove. Tak lupa pula ucapan terima kasih yang sedalam-dalamnya kepada istri dan anak tercinta yang setia dalam menemani peneliti dalam proses pengambilan data ekologi tahap ke-2 sehingga artikel ilmiah ini dapat diselesaikan sesuai dengan perencanaan yang disusun.

\section{DAFTAR PUSTAKA}

Bayu, A. 2009. Hutan mangrove Sebagai Sala Satu Sumber Produk Alam Laut. Oseana.

Bengen DG. 2001a. Sinopsis Ekosistem dan Sumberdaya Alam Pesisir dan Laut. Pusat Kajian Sumberdaya Pesisir dan Laut, Institut Pertanian Bogor.

Bengen DG. 2001b. Pengenalan dan Pengelolaan Ekosistem Mangrove. Pusat Kajian Sumberdaya Pesisir dan Laut, Institut Pertanian Bogor.

Dahuri, R., V.P.H. Nikijuluw, Manadyanto, L. Adrianto dan Sukardi., 1996. Studi Pengembangan Kebijaksanaan Ekonomi Lingkungan. Pusat Penelitian Lingkungan Hidup IPB dan Kantor Menteri Negara Lingkungan Hidup.

Gazali M, Nufus H, Nurjanah, Zuriat. 2019. Eksplorasi potensi senyawa bioaktif ekstrak daun nipah (Nypa fruticans Wurmb) asal pesisir Aceh Barat sebagai Antioksidan. Jurnal Pengolahan Hasil Perikanan Indonesia. 22(1): 155-163.

Hermalena, L., R. Tamin, E. Kamal, dan J.S. Bujang. 1999. Studi zonasi hutan mangrove di Pulau Unggas, Air Bangis, Pasaman. Dalam : Soemodihardjo, S., K. Romimohtarto, dan Suhardjono (Redaksi). Prosiding Seminar VI Ekosistem Mangrove. 


\section{JURNAR \AA (0)T ILMU KELAUTAN}

Volume I, Nomor 1, 2019

Panitia Program MAB-LIPI : 135139.

Irawan B. 2003. Kondisi Vegetasi Mangrove di Pulau Bintan, Kabupaten Kepulauan Riau dalam Burhanuddin dkk (ed.) Kondisi Ekosistem Pesisir Pulau Bintan. Pusriswilnon-BRKPDep. KP. ISBN 979-98165-0-5; hlm 50-58.

Jupri, A. 2006. Inventarisasi species mangrove di Teluk Kertasari, Sumbawa Barat. Biota XI (3) : 196-198.

Pramudji dan A. Sediadi, 1999. Potensi hutan mangrove di Psesisir Teluk Kayeli, Pulau Buru, Maluku Tengah. Dalam : Soemodihardjo, S., K. Romimohtarto, dan Suhardjono (Redaksi). Prosiding Seminar VI Ekosistem Mangrove. Panitia Program MAB-LIPI : 149156.

Pramudji, 2003. Kenekaragaman flora di hutan mangrove kawasan pesisir Teluk Mandar, Polewali, Propinsi Sulawesi Selatan : Kajian pendahuluan. Biota VIII (3) : 135142.

Rahawarin, Y.Y. 2005. Komposisi vegetasi mangrove di Muara Sungai Siganoi Sorong Selatan, Papua. Biota X (3) : 134-140.

Ramanathan, Umamaheshwari .G, dan R. Shanmugapriya. 2012. Antioxidant and Radical Scavenging effect of Ipomoea pes-caprae Linn. R.BR. International Journal of PharmTech Research. Vol.4, No.2, pp 848-851.

Sahoo, G, Mulla N.S.S, Ansari, ZA, Mohandas, C. 2012. Antibacterial activity of mangrove leaf extracts against human pathogent. Indian J. Pharm. Sci. 74 (4) : 349.

Suhardjono. 2001. Permudaan alami hutan mangrove Gosong Telaga, SingkilAceh Selatan. Ekologi Indonesia III (1) : 51-58.
Available online at:

http://utu.ac.id/index.php/jurnal.html

Saparinto, C., 2007. Pendayagunaan Ekosistem Mangrove. Penerbit Dahara Prize. Semarang. p 236. 